\title{
A modelling approach to reconstruct Little Ice Age climate from remote-sensing glacier observations in southeastern Tibet
}

\author{
Eva HUINTJES, David LOIBL, Frank LEHMKUHL, Christoph SCHNEIDER* \\ Department of Geography, RWTH Aachen University, Aachen, Germany \\ Correspondence: Eva Huintjes <eva.huintjes@geo.rwth-aachen.de>
}

\begin{abstract}
We use numerical modelling of glacier mass balance combined with recent and past glacier extents to obtain information on Little Ice Age (LIA) climate in southeastern Tibet. We choose two glaciers that have been analysed in a previous study of equilibrium-line altitudes (ELA) and LIA glacier advances with remote-sensing approaches. We apply a physically based surface energy- and mass-balance model that is forced by dynamically downscaled global analysis data. The model is applied to two glacier stages mapped from satellite imagery, modern (1999) and LIA. Precipitation scaling factors (PSF) and air temperature offsets (ATO) are applied to reproduce recent ELA and glacier mass balance (MB) during the LIA. A sensitivity analysis is performed by applying seasonally varying gradients of precipitation and air temperature. The calculated glacier-wide MB estimate for the period 2000-12 is negative for both glaciers $\left(-992 \pm 366 \mathrm{~kg} \mathrm{~m}^{-2} \mathrm{a}^{-1}\right.$ and $\left.-1053 \pm 258 \mathrm{~kg} \mathrm{~m}^{-2} \mathrm{a}^{-1}\right)$. Relating recent and LIA PSF/ATO sets suggests a LIA climate with $\sim 8-25 \%$ increased precipitation and $\sim 1-2.5^{\circ} \mathrm{C}$ lower mean air temperature than in the period $2000-12$. The results only provide an order of magnitude because deviations in other input parameters are not considered.
\end{abstract}

KEYWORDS: energy balance, glacier mass balance, glacier modelling, mountain glaciers, paleoclimate

\section{INTRODUCTION}

Temperate glaciers in the eastern Nyainqêntanglha Range, southeastern Tibet, are highly sensitive to climate variations (Yang and others, 2011; Yao and others, 2012). Therefore, this region is of specific interest regarding late-Holocene variability of the monsoonal climate in High Asia (Su and Shi, 2002). Due to its remoteness, the availability of climate data and glaciological in situ observations in this area is limited. Recent remote-sensing studies have shown that glacier mass loss in this area distinctly exceeds the overall average in High Asia (Gardelle and others, 2013a,b; Neckel and others, 2014).

Prominent Little Ice Age (LIA) moraines are abundant in the eastern Nyainqêntanglha Range and can be mapped by remote-sensing techniques (Loibl and others, 2014). The regional LIA maximum glacier advance occurred during the late 17 th to early 18th centuries (Bräuning and Lehmkuhl, 1996; Bräuning, 2006; Zhu and others, 2013; Loibl and others, 2015). All glaciers in the region retreated considerably from their LIA extent to modern positions (Loibl and Lehmkuhl, 2014). Knowledge of the palaeoclimatic forcing and glacier dynamics behind these changes is, however, lacking (Loibl and others, 2015).

In this study we apply the 'COupled Snowpack and Ice surface energy and MAss balance model' (COSIMA; Huintjes and others, 2015a) to calculate the spatially distributed surface energy-balance (SEB) and mass-balance (MB) components as well as the equilibrium-line altitude (ELA) for two selected glaciers in the eastern Nyainqêntanglha Range. The model is forced by high-resolution atmospheric model results from the High Asia Refined Analysis (HAR; Maussion and others, 2014). COSIMA is applied to two glacier stages mapped from satellite imagery:

*Present address: Department of Geography, Humboldt Universität zu Berlin, Berlin, Germany. modern (1999) and LIA. Precipitation scaling factors (PSF) and air temperature offsets (ATO) are applied to the HAR data to reproduce both the modern and LIA glacier characteristics. The derived palaeoclimatic PSF/ATO sets that are suitable for simulating LIA glacier MB are evaluated and compared to temperature and precipitation reconstructions from palaeoclimatic proxy records. We focus on the question of whether COSIMA can estimate modern and LIA glacier MB and ELA when solely based on input from an atmospheric model and remote-sensing data. We further analyse selected patterns in the SEB and MB components and their differences between recent and LIA climate.

\section{STUDY AREA}

The eastern Nyainqêntanglha is an east-west-trending mountain range that stretches from the Tibetan Plateau in the west to the Great Gorges in the east (Fig. 1). The region is a high mountain environment with numerous summits $>6000 \mathrm{~m}$ a.s.l. and a maximum elevation of $7151 \mathrm{~m}$ a.s.l. at Gyala Peri mountain. During late spring and summer, the local climate is controlled by warm-wet monsoonal air masses entering the study area predominantly from the south through the Yarlung Tsangpo-Brahmaputra valley (Yang and others, 2008; Molnar and others, 2010). The monsoonal air masses convey large amounts of moisture and make the eastern Nyainqêntanglha Range the region with the highest average precipitation rates of the entire Tibetan Plateau (Maussion and others, 2014). More than $80 \%$ of the annual precipitation occurs from June to September (Zhu and others, 2013). The eastern Nyainqêntanglha Range marks a transition zone between the subtropical warm-humid climates in the forelands and the continental high-mountain climates on the Tibetan Plateau (Domrös and Peng, 1988; Maussion and others, 2014). As a consequence, annual precipitation amounts exhibit a distinct southeast-northwest gradient, ranging from $>6000 \mathrm{mma}^{-1}$ at the southern foothills to 

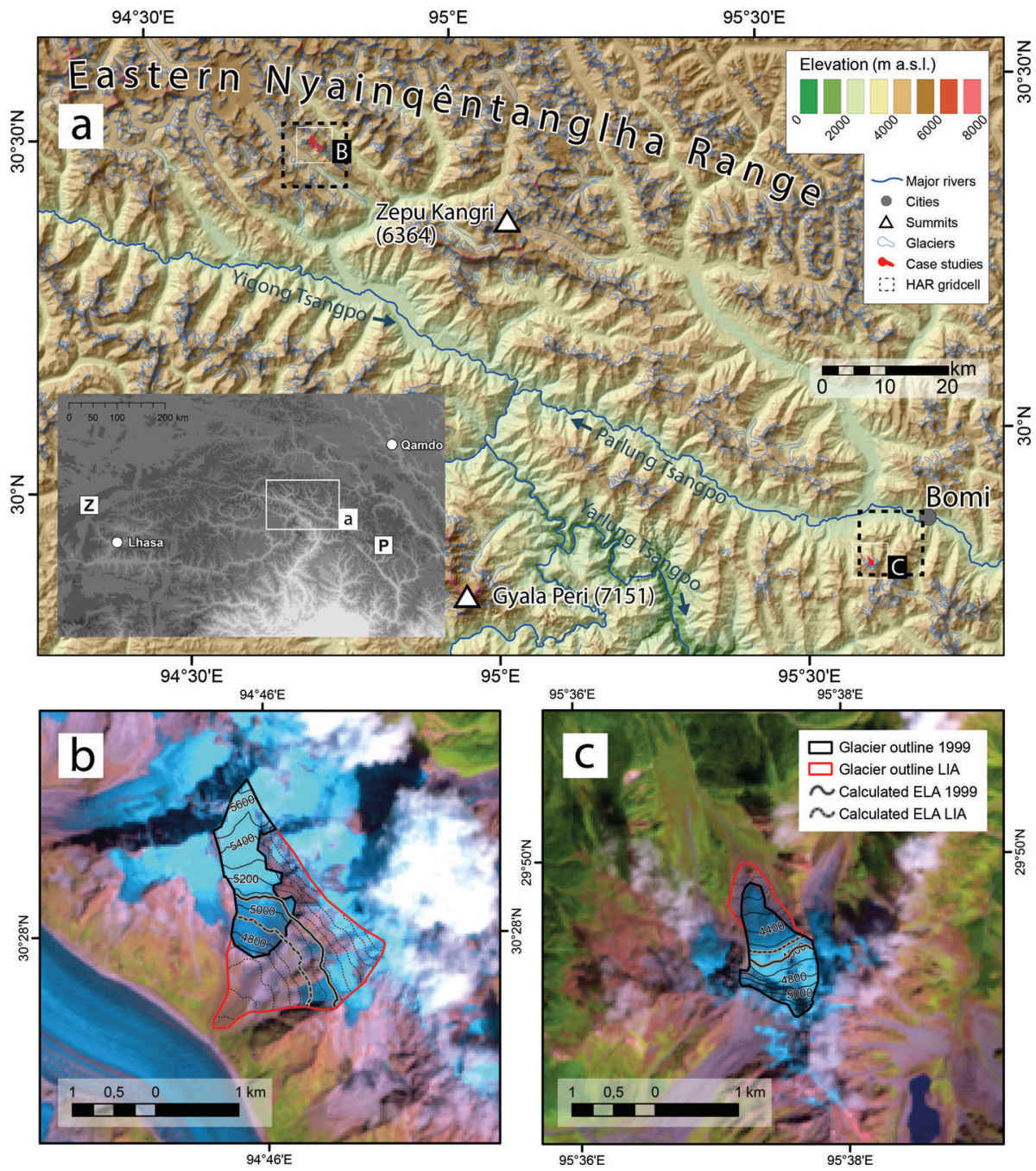

Fig. 1. Regional setting in the eastern Nyainqêntanglha Range, southeast Tibet. (a) Overview map and (b, c) details of the studied glaciers, including contours as well as their 1999 and reconstructed LIA outlines (Loibl and others, 2015). Background to maps (b) (glacier1) and (c) (glacier2) is a Landsat ETM+ scene from 23 September 1999 in channels 5-4-3. The regional overview map includes the locations of Parlung glaciers $(\mathrm{P})$ and Zhadang glacier (Z).

$<500 \mathrm{~mm} \mathrm{a}^{-1}$ at the fringe of the Tibetan Plateau; average annual air temperatures decrease from $\sim+15$ to $>-5^{\circ} \mathrm{C}$ along the same transect (Maussion and others, 2014). During the winter months the westerlies dominate the circulation patterns, conveying mainly cold-dry air masses from the Tibetan Plateau.

For glaciers in this area, the climate poses a coincidence of accumulation and ablation during the summer months. According to Yang and others $(2011,2013)$, glaciers in the region are exposed to a maritime temperature regime. They further show remarkably high ice flow velocities (Zhou and others, 1991). For example, Zheng and others (1999) measured flow rates of 438 and $533 \mathrm{~m} \mathrm{a}^{-1}$ for Azha $\left(29^{\circ} 32.05^{\prime} \mathrm{N}, 9^{\circ} 06.06^{\prime} \mathrm{E}\right)$ and Minyong $\left(28^{\circ} 26.330^{\prime} \mathrm{N}\right.$, $\left.98^{\circ} 41.010^{\prime} \mathrm{E}\right)$ glaciers, respectively. Conversely, the climate makes winter a season of relative stability for the glaciers. According to Maussion and others (2014), this region is in the transition zone between 'spring-accumulation type' and 'summer-accumulation type' glaciers due to the interplay of Indian summer monsoon and East Asian summer monsoon.

Large moraines encompassing the proglacial areas are abundant in the eastern Nyainqêntanglha Range. Several studies have focused on mapping and dating these landforms at different glaciers. Their findings strongly point to the LIA as the major period of formation of these moraine systems, with the regional maximum glacier advance occurring between 1650 and 1800 CE (e.g. Bräuning and Lehmkuhl, 1996; Bräuning, 2006; Zhu and others, 2013; Xu and $\mathrm{Yi}, 2014$; Loibl and others, 2015).

Few reconstructions of late-Holocene climate are available. Zhu and others (2011) present a summer temperature curve covering the last $\sim 600$ years based on dendroclimatological proxy data. Their results show that the period 1570-1850 CE was particularly cold, peaking in the late 17 th and early 18 th centuries with temperatures $\sim 2^{\circ} \mathrm{C}$ lower than today. A tree-ring $\delta^{18} \mathrm{O}$ study by Wernicke and others (2014) found that higher relative humidity than today prevailed throughout the LIA. These results are consistent with the tree ring $\delta^{18} \mathrm{O}$-based findings of Grießinger and others (2011) from Reting near Lhasa, indicating that LIA climate was comparatively wet in the wider region.

The two glaciers investigated in this study are located in different parts of the eastern Nyainqêntanglha Range (Fig. 1b and c). Considering the pronounced topographic and climatic gradients within the study area, the $\sim 150 \mathrm{~km}$ linear distance between the two case studies implies distinctly differing local climates. The two glaciers are debris-free slope glaciers of relatively simple geometry, i.e. without 
pronounced changes in aspect or nickpoints in their longitudinal profiles. As of September 1999, the glaciers in Figure $1 \mathrm{~b}$ and $\mathrm{c}$ ranged from 4600 to $\sim 5740 \mathrm{~m}$ a.s.l. (area $1.09 \mathrm{~km}^{2}$, length $1.85 \mathrm{~km}$ ) and 4100 to $\sim 5150 \mathrm{~m}$ a.s.l. (area $0.88 \mathrm{~km}^{2}$, length $1.3 \mathrm{~km}$; Fig. 1c) in altitude, respectively. The corresponding LIA moraines are clearly visible in the satellite imagery and located at $\sim 4320$ (Fig. 1b) and $4000 \mathrm{ma.s.l}$. (Fig. 1c). The distinct terminal moraine suggests that glacier1 in Figure $1 \mathrm{~b}$ was not a tributary to Qiaqing, the large adjacent valley glacier, during the LIA. Due to these characteristics the two glaciers are chosen for the application of COSIMA. Both glaciers are listed in the Randolph Glacier Inventory (Pfeffer and others, 2014) under IDs RGI40-13.21558 (Qiaqing glacier and glacier1, Fig. 1b) and RGI40-15.08487 (glacier2, Fig. 1c).

\section{DATA}

\subsection{High Asia Refined Analysis}

For the simulation of SEB and MB under present-day climate we use hourly results from the HAR at $10 \mathrm{~km}$ resolution between October 2000 and 2012 (Maussion and others, 2014) to force COSIMA. Incoming shortwave radiation $\left(\mathrm{W} \mathrm{m}^{-2}\right)$, air temperature $\left({ }^{\circ} \mathrm{C}, 2 \mathrm{~m}\right)$, relative humidity $(\%$, $2 \mathrm{~m})$, air pressure $(\mathrm{hPa})$, wind speed $\left(\mathrm{m} \mathrm{s}^{-2}, 10 \mathrm{~m}\right)$, all-phase precipitation $(\mathrm{mm})$ and cloud cover fraction are extracted from the gridcell containing the respective glacier. Altitudinal gradients of most input parameters are required to run the distributed model for the two glaciers (Huintjes and others, 2015a). The altitude dependency for the period 2000-12 is calculated from the mean value of each input parameter of the HAR $10 \mathrm{~km}$ gridcell containing each glacier and its eight surrounding gridcells. The size of the gridcells causes the inclusion of glaciated and unglaciated terrain in each cell (Fig. 1; see Section 4.4). The altitude of the nine gridcells ranges from 3595 to $4988 \mathrm{~m}$ a.s.l. for glacier1 and from 3645 to $4038 \mathrm{ma.s.l}$. for glacier2. Resulting average annual gradients for glacier1 (Fig. 1b) are $-0.0066^{\circ} \mathrm{C} \mathrm{m}^{-1}$ for air temperature $\left(T_{\text {air }}\right),+0.012 \% \mathrm{~m}^{-1}$ for relative humidity $(\mathrm{rH}),-0.076 \mathrm{hPa} \mathrm{m}^{-1}$ for air pressure $(p)$ and $+0.045 \% \mathrm{~m}^{-1}$ for precipitation. For glacier2 (Fig. 1c), respective gradients are $-0.0050^{\circ} \mathrm{C} \mathrm{m}^{-1}$ for $T_{\text {air }}+0.008 \% \mathrm{~m}^{-1}$ for $\mathrm{rH},-0.080 \mathrm{hPa} \mathrm{m}^{-1}$ for $p$, and $+0.074 \% \mathrm{~m}^{-1}$ for precipitation. Gradients for $T_{\text {air }}$ and precipitation from HAR are of the same order of magnitude as the average annual gradients derived by Immerzeel and others (2014) from in situ measurements in the glacierized Langtang valley in the Nepalese Himalaya. Based on the gradients calculated from the HAR data the altitude dependency of wind speed (ws) and cloud cover fraction $(N)$ is not significant. Therefore, we apply no altitudinal gradient for ws and $N$ but use hourly values for each glacier. Incoming shortwave radiation $\left(\mathrm{SW}_{\mathrm{in}}\right)$ from the HAR gridcells containing glacier1 and glacier2 is used to correct the potential $S_{\text {in }}\left(S_{\text {in,pot }}\right)$ from the applied radiation model for cloud cover. Details of this procedure are outlined in Section 4.

Mölg and others (2012) obtained a scaling factor of 0.56 for the amount of HAR precipitation from in situ measurements at Zhadang glacier under recent climate. This factor reflects a possible overestimation of precipitation within $H A R$, as well as measurement errors from the precipitation gauge and/or the loss of snow on the glacier by wind drift (Mölg and others, 2012). The factor was applied in the HAR forced COSIMA runs 2001-11 for Zhadang glacier (Huintjes and others, 2015a) and 2001-11 for Purogangri ice cap, central Tibetan Plateau (Huintjes and others, 2015b). Due to a lack of precipitation measurements at the two glaciers in the eastern Nyainqêntanglha Range we also apply this scaling factor on HAR precipitation in the first-guess model runs within this study.

\subsection{DEMs and glacier extents}

COSIMA is run on the SRTM (Shuttle Radar Topography Mission, acquired February 2000) DEM (Rabus and others, 2003) resampled to $180 \mathrm{~m}$ resolution in order to limit computing time. Based on a Landsat Enhanced Thematic Mapper Plus (ETM+) satellite image from 23 September 1999, recent and maximum LIA glacier extents have been mapped by Loibl and others (2014). The LIA glacier extents were derived from moraine mapping (Fig. $1 \mathrm{~b}$ and $\mathrm{c}$ ). The recent and LIA ELA were calculated by an optimized toe-toridge altitude method (TRAM; Loibl and Lehmkuhl, 2014; Loibl and others, 2014), explicitly considering local topography and morphological glacier properties. Absolute elevations were derived from both Advanced Spaceborne Thermal Emission and Reflection Radiometer (ASTER) and SRTM elevation data since the two DEMs show considerable local voids or deficiencies.

\section{METHODS}

\subsection{Surface energy- and mass-balance model}

The physically based surface energy- and mass-balance model COSIMA is described in detail in Huintjes and others (2015a), so here we only provide a brief summary. The model has been applied and evaluated at Zhadang glacier, $\sim 400 \mathrm{~km}$ northwest of glacier1 (Fig. 1) for point locations as well as for spatially distributed model runs using ablation stake and time-lapse camera data (Huintjes and others 2015a). Since no atmospheric or glaciological in situ measurements are available for the two glaciers in this study, the model structure, parameterizations, constants and assumptions used for Zhadang glacier are applied here. Similar models that couple a SEB to a subsurface snow model were applied to Zhadang glacier by Mölg and others (2012) and to Parlung glaciers No. 4 and No. 94 in the Hengduan Shan by Yang and others (2011, 2013).

COSIMA does not account for glacier dynamics and changes in glacier geometry over the 12 year simulation. This implies that we assume that overall flux divergence across the glacier is zero. COSIMA computes surface MB at an hourly time step as the sum of mass gains by solid precipitation, refreezing of liquid water in the snowpack and deposition, and of mass losses by surface melt, subsurface melt and sublimation. The SEB equation governs the calculation of the mass fluxes:

$$
F=\mathrm{SW}_{\text {in }} \cdot(1-\alpha)+\mathrm{LW}_{\text {in }}+\mathrm{LW}_{\text {out }}+Q_{\text {sens }}+Q_{\text {lat }}+Q_{\mathrm{G}} .
$$

The SEB consists of incoming shortwave radiation $\left(S_{\mathrm{in}}\right)$, surface albedo $(\alpha)$, incoming and outgoing longwave radiation ( $L W_{\text {in }}$ and $\left.L W_{\text {out }}\right)$, the turbulent sensible and latent heat fluxes $\left(Q_{\text {sens }}\right.$ and $\left.Q_{\text {lat }}\right)$ and the ground heat flux $\left(Q_{\mathrm{G}}\right)$. $Q_{\mathrm{G}}$ consists of fluxes due to heat conduction $\left(Q_{\mathrm{C}}\right)$ and penetrating shortwave radiation (QPS). Heat flux from liquid precipitation is neglected. Energy fluxes directed towards the surface are defined as positive. The resulting flux $F$ is equal to the melt energy at the surface $\left(Q_{\text {melt }}\right)$ only if the surface temperature $\left(T_{\mathrm{s}}\right)$ is at the melting point $(273.15 \mathrm{~K}) . T_{\mathrm{s}}$ is calculated 
Table 1. Vertical precipitation $(P)$ and air temperature $(T)$ gradients calculated from HAR for four defined seasons at glacier1 and glacier2 for October 2000-September 2012

\begin{tabular}{|c|c|c|c|c|}
\hline & \multicolumn{2}{|c|}{ Glacier1 } & \multicolumn{2}{|c|}{ Glacier2 } \\
\hline & Precipitation & Temperature & Precipitation & Temperature \\
\hline & $\% \mathrm{~m}^{-1}$ & ${ }^{\circ} \mathrm{Cm}^{-1}$ & $\% \mathrm{~m}^{-1}$ & ${ }^{\circ} \mathrm{Cm}^{-1}$ \\
\hline $\begin{array}{l}\text { Pre-monsoon } \\
\text { (1 Mar-14 Jun) }\end{array}$ & 0.035 & -0.0067 & 0.053 & -0.0055 \\
\hline $\begin{array}{l}\text { Monsoon } \\
\text { (15 Jun-30 Sep) }\end{array}$ & 0.044 & -0.0059 & 0.061 & -0.0052 \\
\hline $\begin{array}{l}\text { Post-monsoon } \\
(1 \text { Oct-30 Nov) }\end{array}$ & 0.046 & -0.0069 & 0.058 & -0.0050 \\
\hline $\begin{array}{l}\text { Winter } \\
\text { (1 Dec-28 Feb) }\end{array}$ & 0.056 & -0.0070 & 0.124 & -0.0042 \\
\hline Annual & 0.045 & -0.0066 & 0.074 & -0.0050 \\
\hline
\end{tabular}

iteratively through Eqn (1) from the energy available at the surface. Equilibrium between the SEB fluxes is required. In the case when $T_{s}$ exceeds the melting point, it is reset to $273.15 \mathrm{~K}$ and the remaining energy flux $F$ equals $Q_{\text {melt }}$.

Hourly $S_{W} W_{\text {in,pot }}$ is derived from a radiation model after Kumar and others (1997) that computes clear-sky direct and diffuse $S_{W}$ in as a function of geographical position and terrain effects. The radiation model runs on the SRTM DEM $(180 \mathrm{~m}) . \mathrm{SW}_{\text {in, pot }}$ is corrected for cloud cover through HAR $\mathrm{SW}_{\text {in. }}$. For this correction we choose a DEM pixel in the middle part of each glacier where $S_{W}$ in, pot shows minimum terrain shading and a similar daily and annual cycle to that of HAR SW in. The correction of SW in,pot for cloud coverage and terrain effects is carried out following the approach of Huintjes and others (2015a) for the case of Zhadang glacier.

$\mathrm{LW}_{\text {in }}$ and $\mathrm{LW}_{\text {out }}$ are obtained by the Stefan-Boltzmann law. For $L_{\text {in, }}$ the atmospheric emissivity is calculated from $N, T_{\text {air }}$ and water vapour pressure after Klok and Oerlemans (2002). For COSIMA simulations at Zhadang glacier, values for site-specific constants within the parameterization are adopted from Klok and Oerlemans (2002; Huintjes and others, 2015a). Since no atmospheric measurements are available for the two glaciers in this study, a site-specific recalibration of model parameters as suggested by Juszak and Pellicciotti (2013) is not possible. Turbulent heat fluxes $Q_{\text {sens }}$ and $Q_{\text {lat }}$ are calculated through the bulk aerodynamic method and are corrected for stable conditions. Besides $T_{\mathrm{s}}$ the surface characteristics of each DEM pixel of the glacier are defined by its surface albedo and its surface roughness. Both parameters are determined at every time step within COSIMA and change linearly from fresh to aged snow depending on time. Constant values are assumed for bare ice surfaces.

The subsurface model of COSIMA uses a vertical layer structure that consists of layers with an equal thickness of $0.2 \mathrm{~m}$. Each subsurface ice layer is characterized by a temperature, density and depth. The initial temperature profile is linearly interpolated between $T_{\text {air }}\left(=T_{\mathrm{s}}\right)$ and a constant bottom temperature of $-5^{\circ} \mathrm{C}$ adopted from measurements at Zhadang glacier (Huintjes and others, 2015a). In each time step the subsurface temperature profile is solved from the thermodynamic heat equation. Glacierwide initial snow depth is set to zero. Thus, the subsurface density profile is initialized with a constant density of $917 \mathrm{~kg} \mathrm{~m}^{-3}$ for glacier ice.
To determine the amount of solid precipitation that accumulates on the glacier surface we apply a hyperbolictangent function (Möller and others, 2007) to HAR precipitation. The function describes the transition between solid and liquid precipitation in a temperature range between $+1^{\circ} \mathrm{C}$ and $+5^{\circ} \mathrm{C}$. The amount of solid precipitation is considered as added mass in the subsurface density profile with a density of $250 \mathrm{~kg} \mathrm{~m}^{-3}$ (Huintjes and others, 2015a).

Calculations of Mölg and others (2012) and Huintjes and others (2015a) under recent climate suggest the application of a PSF of 0.56 to the amount of HAR precipitation at Zhadang glacier. This implies that a degree of uncertainty has to be considered for the PSF in any case. An air temperature increase has an effect on $\mathrm{MB}$ and ELA similar to a precipitation correction towards less precipitation. We consider positive ATO to allow for higher PSF and therefore less precipitation correction for recent climate. Thus, we vary PSF between 0.36 and 1.35 and ATO between $0^{\circ} \mathrm{C}$ and $+4^{\circ} \mathrm{C}$ (Table 3 further below) for both glaciers so that the average ELA over 2000-12 calculated with COSIMA agrees with the remote-sensing derived ELA of Loibl and others (2014) for 1999.

\subsection{Little Ice Age simulation}

We assume that glaciers have been in equilibrium over a short period during the change from LIA climate with advancing glaciers to present-day climate with shrinking glaciers. To simulate LIA glacier MB and ELA we use the same 12 year period of HAR results for model forcing as for present-day simulations. Thus, we assume that the period 2000-12 is a representative decade also for LIA climate. We run COSIMA with PSF from 0.36 to 1.75 and ATO from $-4^{\circ} \mathrm{C}$ to $+3{ }^{\circ} \mathrm{C}$ (Table 3 further below) in order to derive an average $\mathrm{MB}$ that is in climatic equilibrium (zero $\mathrm{MB}$ ) over the 12 year period for the reconstructed LIA glacier extents (Fig. 1). All other input parameters as well as derived altitudinal gradients remain unchanged compared to present-day conditions.

Loibl and others (2014) summarize that glaciers in the eastern Nyainqêntanglha Range during the LIA have been strongly influenced by small-scale local climate variability. Changed dynamics of Indian summer monsoon and East Asian summer monsoon, implying local differences between present-day and LIA wind speed, are not evident from palaeoclimate records as obtained by Loibl and others (2014).

\subsection{Vertical gradients of air temperature and precipitation}

Immerzeel and others (2014) showed for the Langtang valley that altitudinal precipitation and air temperature gradients vary both diurnally and seasonally in relation to the water vapour content of the atmosphere. To reveal the effects of seasonally varying gradients of precipitation and temperature on the derived PSF/ATO sets compared to an average gradient, we calculated vertical seasonal gradients for premonsoon, monsoon, post-monsoon and winter seasons (Table 1). Seasons are defined by evaluating the HAR for the characteristic temperature and precipitation patterns of each season (Immerzeel and others, 2014; results not shown). The seasonality within the HAR agrees with the definition of seasons as chosen by Immerzeel and others (2014). Vertical gradients for precipitation vary between $3.5 \%(100 \mathrm{~m})^{-1}$ and $5.6 \%(100 \mathrm{~m})^{-1}$ at glacier1 and between 
$5.3 \%(100 \mathrm{~m})^{-1}$ and $12.4 \%(100 \mathrm{~m})^{-1}$ at glacier2 (Table 1$)$. The seasonal pattern of precipitation gradients derived from HAR is similar to that calculated by Immerzeel and others (2014, results not shown). A positive vertical gradient is apparent in all seasons. At both glaciers the average gradient is highest in winter and lowest during pre-monsoon (Table 1). Derived seasonal air temperature lapse rates are more homogeneous for the two regions and vary between $-0.59^{\circ} \mathrm{C}(100 \mathrm{~m})^{-1}$ and $-0.70^{\circ} \mathrm{C}(100 \mathrm{~m})^{-1}$ (glacier 1$)$ and between $-0.42^{\circ} \mathrm{C}(100 \mathrm{~m})^{-1}$ and $-0.55^{\circ} \mathrm{C}(100 \mathrm{~m})^{-1}$ (glacier2). A peak in the lapse rate in the pre-monsoon season as reported by Immerzeel and others (2014) is only visible at glacier2 (Table 1).

The application of $10 \mathrm{~km}$ resolution atmospheric model data limits the simulation of complex, small-scale atmospheric processes. However, vertical seasonal gradients for precipitation and air temperature derived from HAR are within the range given by Immerzeel and others (2014), Heynen and others (2016) and Kattel and others (2012). The effects of seasonally varying gradients on MB and ELA are evaluated in a sensitivity analysis.

\subsection{Uncertainty assessment}

As presented by Xu (2014), the ELA of a glacier may vary with different climate conditions while the average $M B$ is similar. Conversely, a similar average ELA may result from different overall MB. In this study, the given uncertainties are the ranges of plausible ELA and $M B$ derived from the COSIMA runs with PSF/ATO sets that result in a similar average ELA for recent climate or in a zero $\mathrm{MB}$ for LIA glacier area and LIA climate.

The applied altitudinal gradients of the forcing parameters of COSIMA are computed over an area of $900 \mathrm{~km}^{2}$ (nine HAR gridcells). The size of each gridcell causes the inclusion of both glaciated and unglaciated surfaces in one cell. Therefore, the derived gradients do not capture the microclimate of the respective glacier valleys and may differ from the gradients in the glacier boundary layer. Comparison of altitudinal gradients from in situ measurements and HAR at Zhadang glacier for 2009-12 showed that altitudinal gradients derived from HAR represent the glacier boundary conditions accurately (vertical air temperature gradient to within $\pm 0.04^{\circ} \mathrm{C}(100 \mathrm{~m})^{-1}$; vertical precipitation gradient to within $\pm 0.4 \%(100 \mathrm{~m})^{-1}$; Huintjes and others, 2015a). Furthermore, average annual and seasonal gradients for precipitation and air temperature derived from HAR are in the same order of magnitude as derived by Immerzeel and others (2014) in the Langtang valley.

The spatial resolution of the applied DEM for COSIMA simulations $(180 \mathrm{~m})$ can lead to large elevation steps between neighbouring pixels, which limits the precision of the calculated ELA. Considering only pixels along the central flowlines, differences between neighbouring pixels range from 50 to $120 \mathrm{~m}$. However, for the ELA calculation, all DEM pixels of the glacier-covered area are considered so that elevation steps for the resulting ELA are decreased to a maximum value of $20 \mathrm{~m}$.

The ELA calculated using the TRAM method is based on measurements of the elevations of two points, i.e. the average ridge altitude and the lowest point of the glacier. Consequently, a direct quantification of measurement uncertainties is of doubtful value for this method. Since reliable $M B$ measurements are lacking for the glaciers measured in Loibl and others (2014), a quantification of absolute error is also not possible. Owing to the simplifying concept of the TRAM calculation, the reconstructed ELAs should, however, be considered as estimates rather than firmly established values for individual glaciers (e.g. Benn and Lehmkuhl, 2000).

In summary, uncertainty ranges of the results of this study and of the data used for evaluation cannot be fully quantified. Thus, our results and conclusion can only provide an order of magnitude and absolute values must be treated cautiously due to the partly speculative boundary conditions of the model runs.

\subsection{Spatial transferability of COSIMA}

The physical parameterizations within full energy-balance models such as COSIMA should, in principle, offer a higher spatial transferability between glaciers compared to empirical temperature index models. However, Gabbi and others (2014), MacDougall and others (2011) and MacDougall and Flowers (2010) showed that full energy-balance models produce large errors when forced with off-glacier data that are not representative of the glacier boundary layer or if model parameters and meteorological forcing variables are directly transferred between glaciers. For glaciers with in situ measurements of very good quality and of sufficient length for calibration, the performance of temperature index models is higher than that of full energy-balance models (Gabbi and others, 2014). However, the applicability of temperatureindex models requires a site-specific calibration and they are therefore poorly transferable from one glacier to the other (MacDougall and others, 2011). For full energy-balance models MacDougall and Flowers (2010) identified the parameters ice albedo, initial snow depth and summer snowfall to be most important for improving model performance by local measurements. They achieved a $\leq 15 \%$ uncertainty in calculated surface ablation when transferring both model parameter values and meteorological forcing variables from one glacier site to another. MacDougall and Flowers (2010) use an albedo parameterization that includes two constants that must be found through calibration by in situ measurements. Thus, we believe that the albedo parameterization within COSIMA, that does not include any site-specific adjustment (Huintjes and others, 2015a), is less sensitive to a transfer between glaciers.

The applicability of the $10 \mathrm{~km}$ HAR to force COSIMA was evaluated for Zhadang glacier by Huintjes and others (2015a). Results indicate that $10 \mathrm{~km} \mathrm{HAR}$ is of sufficient quality to reproduce surface height change, mass balance and energy and mass fluxes at Zhadang accurately. Therefore, we assume that COSIMA produces similar good results for glaciers in southeastern Tibet.

Applying the calculated uncertainty of $15 \%$ from MacDougall and Flowers (2010) to total surface ablation estimated from COSIMA (surface melt + sublimation; Table 2) leads to uncertainties of $\pm 376 \mathrm{~kg} \mathrm{~m}^{-2} \mathrm{a}^{-1}$ (2000-12) and $\pm 229 \mathrm{~kg} \mathrm{~m}^{-2} \mathrm{a}^{-1}$ (LIA) for glacier1 and $\pm 383 \mathrm{~kg} \mathrm{~m}^{-2} \mathrm{a}^{-1}$ (2000-12) and $\pm 258 \mathrm{~kg} \mathrm{~m}^{-2} \mathrm{a}^{-1}$ (LIA) for glacier2. These values are close to the uncertainties derived from COSIMA runs with different PSF/ATO sets (Table 2).

\section{RESULTS AND DISCUSSION}

\subsection{Recent MB and ELA}

For glacier1, Loibl and others (2014) derived an ELA of $5105 \mathrm{~m}$ a.s.l. from the Landsat image of 1999. When applying average annual altitudinal gradients for precipitation and 
Table 2. Glacier-wide mean values $\left(\mathrm{W} \mathrm{m}^{-2}\right)$ of energy-flux and mass-balance components as modelled for October 2000-September 2012 and for LIA climate at glacier1 and glacier2 with average annual altitudinal gradients. Given uncertainties are the ranges for plausible $\mathrm{MB}$ and ELA derived from the COSIMA runs with PSF/ ATO sets that result in a similar average ELA or in a zero MB (see also Table 3)

\begin{tabular}{|c|c|c|c|c|}
\hline \multirow{3}{*}{ No. of model runs } & \multicolumn{2}{|c|}{ Glacier1 } & \multicolumn{2}{|c|}{ Glacier2 } \\
\hline & 3 & 5 & 1 & 6 \\
\hline & 2000-12 & LIA & 2000-12 & LIA \\
\hline $\mathrm{SW}_{\text {in }}$ & +248 & +244 & +178 & +182 \\
\hline $\mathrm{SW}_{\text {out }}$ & $-204 \pm 3$ & $-206 \pm 3$ & -149 & $-159 \pm 0.4$ \\
\hline $\mathrm{SW}_{\text {net }}$ & $+44 \pm 3$ & $+38 \pm 3$ & +28 & $+22 \pm 0.4$ \\
\hline $\mathrm{LW}_{\text {in }}$ & $+235 \pm 4$ & $+225 \pm 3$ & +244 & $+237 \pm 1$ \\
\hline $\mathrm{LW}_{\text {out }}$ & $-268 \pm 3$ & $-262 \pm 3$ & -270 & $-266 \pm 1$ \\
\hline $\mathrm{LW}_{\text {net }}$ & $-33 \pm 3$ & $-37 \pm 3$ & -26 & $-29 \pm 0.5$ \\
\hline$Q_{\text {sens }}$ & $+25 \pm 2$ & $+23 \pm 2$ & +24 & $+23 \pm 0.3$ \\
\hline$Q_{\text {lat }}$ & $-12 \pm 1$ & $-13 \pm 1$ & -0.2 & $-2 \pm 0.3$ \\
\hline$Q_{G}$ & $-2 \pm 0.7$ & $-0.3 \pm 0.8$ & +0.4 & $+3 \pm 0.2$ \\
\hline $\mathrm{Q}_{\text {melt }}$ & $-25 \pm 3$ & $-15 \pm 2$ & -26 & $-18 \pm 1$ \\
\hline \multicolumn{5}{|l|}{ Total $\left(\mathrm{kg} \mathrm{m}^{-2} \mathrm{a}^{-1}\right)$} \\
\hline Surface melt & $-2332 \pm 312$ & $-1358 \pm 244$ & -2506 & $-1667 \pm 137$ \\
\hline Subsurface melt & $-151 \pm 151$ & $-39 \pm 0.6$ & -62 & $-45 \pm 3$ \\
\hline Refrozen water & $+170 \pm 10$ & $+166 \pm 20$ & +190 & $+235 \pm 4$ \\
\hline Sublimation & $-173 \pm 4$ & $-167 \pm 0.6$ & -50 & $-56 \pm 1$ \\
\hline Deposition & $+43 \pm 8$ & $+31 \pm 6$ & +48 & $+35 \pm 3$ \\
\hline Solid precipitation & $+1231 \pm 148$ & $+1366 \pm 218$ & +1198 & $+1498 \pm 132$ \\
\hline Mass balance & $-1212 \pm 332$ & $-0.1 \pm 0.6$ & -1182 & $+0.02 \pm 0.1$ \\
\hline
\end{tabular}

air-temperature COSIMA runs with the PSF/ATO combinations $0.56 / \pm 0^{\circ} \mathrm{C}, 0.69 /+1{ }^{\circ} \mathrm{C}$ and $0.81 /+2^{\circ} \mathrm{C}$, each produces an average ELA of $5093 \mathrm{ma.s.l}$. for the period 2000-12 (Table 3). The results from Loibl and others (2014) and COSIMA match very well. The corresponding glacier-wide $\mathrm{MB}$ estimate is clearly negative at $-1212 \pm 332 \mathrm{~kg} \mathrm{~m}^{-2} \mathrm{a}^{-1}$ (Table 2). For glacier2, only one realistic PSF/ATO set could be determined that roughly reproduced the average ELA of $4590 \mathrm{~m}$ a.s.l. as derived by Loibl and others (2014). Therefore, no uncertainty range for $M B$ or any $S E B$ and $M B$ components for glacier2 for the recent climate and average annual altitudinal gradients can be obtained. The model run with $1.35 \pm 0^{\circ} \mathrm{C}$ yields an ELA at $4668 \mathrm{~m}$ a.s.I. (Table 3 ) with a glacier-wide $M B$ estimate of $-1182 \mathrm{~kg} \mathrm{~m}^{-2} \mathrm{a}^{-1}$ for the period 2000-12 (Table 2).

Other MB studies for glaciers in High Asia over a similar time period using satellite data also revealed distinctly negative mass balances, although most of them are less negative than our results for the period 2000-12. Gardelle and others $(2013 \mathrm{a}, \mathrm{b})$ obtained a value of $-330 \pm$ $140 \mathrm{~kg} \mathrm{~m}^{-2} \mathrm{a}^{-1}$ for the eastern Nyainqêntanglha Range (1999-2010). Results of Neckel and others (2014) for the same region are more negative at $-690 \pm 360 \mathrm{~kg} \mathrm{~m}^{-2} \mathrm{a}^{-1}$ (2003-09). Gardner and others (2013) obtained values of $-360 \pm 430 \mathrm{~kg} \mathrm{~m}^{-2} \mathrm{a}^{-1}$ for the Hengduan Shan, $-270 \pm$ $160 \mathrm{~kg} \mathrm{~m}^{-2} \mathrm{a}^{-1}$ for the southern and eastern Tibetan Plateau (including the eastern Nyainqêntanglha Range) and $-800 \pm 220 \mathrm{~kg} \mathrm{~m}^{-2} \mathrm{a}^{-1}$ for the East Himalaya (2003-08). The few existing $\mathrm{MB}$ measurements for single glaciers in the Hengduan Shan over several years (Parlung No. 10, No. 12 , No. 94 , No. 390) yield average MB of $-781 \mathrm{~kg} \mathrm{~m}^{-2} \mathrm{a}^{-1}$, $-1698 \mathrm{~kg} \mathrm{~m}^{-2} \mathrm{a}^{-1},-922 \mathrm{~kg} \mathrm{~m}^{-2} \mathrm{a}^{-1}$ and $-1020 \mathrm{~kg} \mathrm{~m}^{-2} \mathrm{a}^{-1}$ between 2006 and 2011 (Yao and others, 2012; Yang and

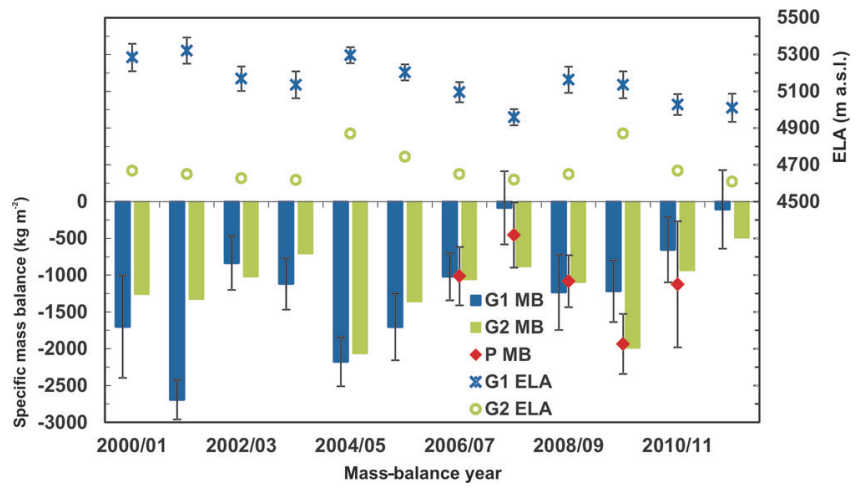

Fig. 2. Annual $M B$ and ELA for the two glaciers shown in Figure 1 for mass-balance $(\mathrm{MB})$ years (1 October-30 September) as calculated from COSIMA, 2000-12 and annual MB for the four Parlung glaciers (No. 10, No. 12, No. 94, No. 390; 'P'), 2006-11 as given in Yao and others (2012). The given $M B$ is the average $M B$ measured over the four Parlung glaciers, with error bars giving the range of the single MB values. For COSIMA, PSF and ATO are varied so that the average modelled ELA over 2000-12 fits to the remote-sensing derived ELA in 1999 of Loibl and others (2014). Given MB and ELA are the means of the sets of reasonable PSF/ ATO combinations for each glacier with average annual altitudinal gradients and the respective results with seasonally varying gradients (combinations noted with asterisk in Table 3). Error bars give the range of plausible ELA/MB derived from the model runs with PSF/ATO sets that result in a similar average ELA and including the sensitivity analysis. Error ranges for ELA also include DEM uncertainty $( \pm 20 \mathrm{~m})$.

others, 2013). Tshering and Fujita (2016) recently published a measured MB of $-1550 \pm 290 \mathrm{~kg} \mathrm{~m}^{-2} \mathrm{a}^{-1}$ for 2003-14 for a small glacier in the Bhutan Himalaya. Average annual MB values derived from COSIMA for glacier1 and glacier2 are very similar to the average annual $\mathrm{MB}$ of the four Parlung glaciers (Fig. 2). Thus, COSIMA simulations for recent climate support the finding of above-average mass loss for glaciers in southeastern Tibet (Yao and others, 2012).

Modelled annual MB and ELA for the two glaciers reveal a similar interannual pattern in most years (Fig. 2). Discrepancies in single years might be the result of different governing air masses at the glacier sites. However, interpretation of the interannual patterns is beyond the scope of this study.

As an example for recent SEB and MB conditions, annual cycles of glacier-wide mean monthly SEB and MB components at glacier 1 as calculated by COSIMA for the PSF/ ATO set $0.69 /+1^{\circ} \mathrm{C}$ for the period $2000-12$ are illustrated in Figure 3. The given pattern and proportion of the SEB and MB fluxes are similar to those of glacier2. Changing to PSF/ATO sets $0.56 / \pm 0^{\circ} \mathrm{C}$ and $0.81 /+2^{\circ} \mathrm{C}$ at glacier 1 only changes the MB components surface melt, subsurface melt and solid precipitation (Table 2). At glacier1, $\mathrm{SW}_{\text {in }}\left(+248 \mathrm{~W} \mathrm{~m}^{-2}\right)$ and $\mathrm{LW}_{\text {in }}\left(+232 \mathrm{~W} \mathrm{~m}^{-2}\right)$ dominate the energy input over the considered period, followed by $Q_{\text {sens }}\left(+25 \pm 2 \mathrm{~W} \mathrm{~m}^{-2}\right)$. Energy sinks at the glacier surface are $\operatorname{LW}_{\text {out }}(-268 \pm$ $\left.2 \mathrm{~W} \mathrm{~m}^{-2}\right), \mathrm{SW}_{\text {out }}\left(-204 \pm 3 \mathrm{~W} \mathrm{~m}^{-2}\right), Q_{\text {melt }}\left(-25 \pm 3 \mathrm{~W} \mathrm{~m}^{-2}\right)$, $Q_{\text {lat }}\left(-12 \pm 1 \mathrm{~W} \mathrm{~m}^{-2}\right)$ and $Q_{\mathrm{G}}\left(-2 \pm 0.7 \mathrm{~W} \mathrm{~m}^{-2}\right)$, making net shortwave radiation $\left(\mathrm{SW}_{\text {net }}+44 \pm 3 \mathrm{~W} \mathrm{~m}^{-2}\right.$; see Table 1) the most important energy source, followed by $Q_{\text {sens }}$.

At glacier2, $\mathrm{LW}_{\mathrm{in}}\left(+244 \mathrm{~W} \mathrm{~m}^{-2}\right)$ clearly dominates over $\mathrm{SW}_{\text {in }}\left(+178 \mathrm{~W} \mathrm{~m}^{-2}\right)$ as energy source for the glacier surface. This can be explained by a stronger influence of 


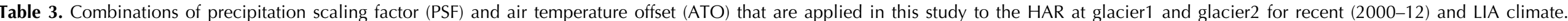

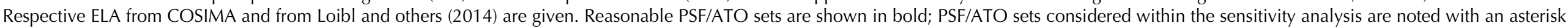

2000-12

Glacier1 / average annual

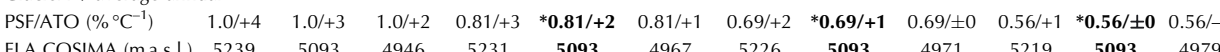

Glacier 1 / seasonally varying

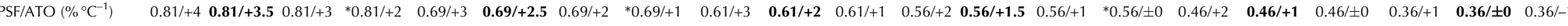

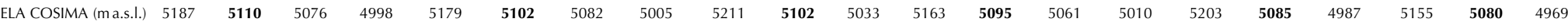

Glacier1

ELA Loibl and others 5105

(2014) (ma.s.l.)

Glacier2 / average annual

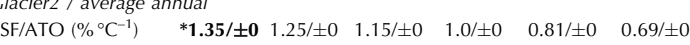

ELA COSIMA (ma.s.l.) 4660

Glacier2 / seasonally varying

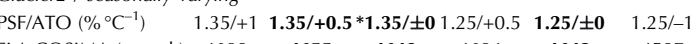

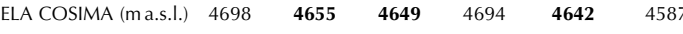

Glacier2

Glacier2 ELA Loibl

and others (2014

4590

(ma.s.l.)

Glacier1 / average annual

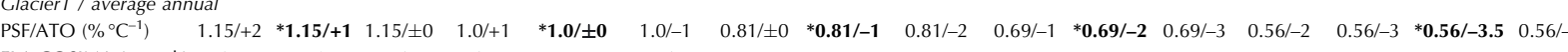

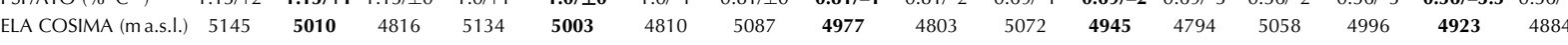

Glacier1 / seasonally varying

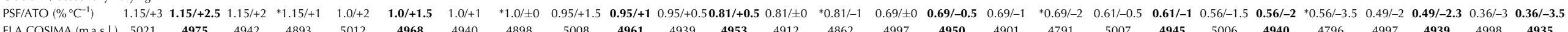

Glacier 1

Clacier1 1

(2014) (ma.s.l.)

Glacier2 / average annual

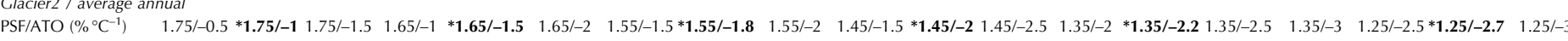

ELA COSIMA (ma.s.l.) 46601

Clacier $2 /$ seas

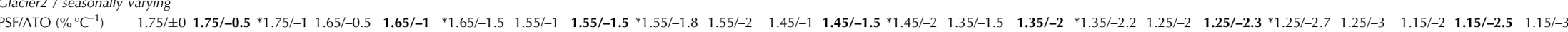

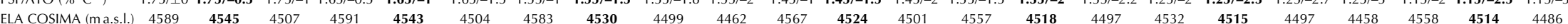

Glacier2

ELA Loibl and others 4522

(2014) (ma.s.l.) 

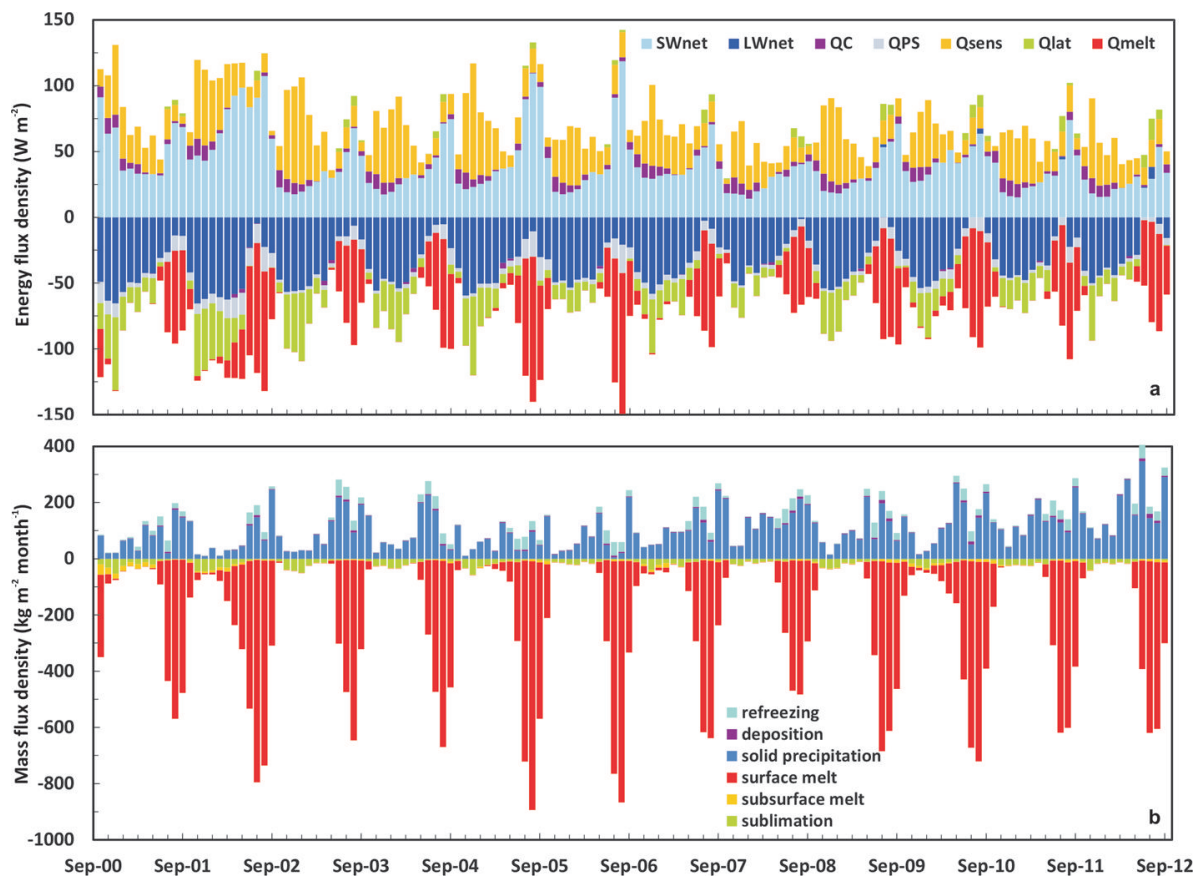

Fig. 3. Glacier-wide monthly (a) SEB components (abbreviations are explained in the text) and (b) MB components from October 2000 to September 2012 at glacier1 for one of the derived PSF/ATO sets $(0.69 \pm 1 \mathrm{~K})$ with average annual altitudinal gradients.

monsoonal air masses in the southeastern part of the eastern Nyainqêntanglha associated with increased cloud cover. Energy sinks at glacier2 are $\mathrm{LW}_{\text {out }}\left(-270 \mathrm{~W} \mathrm{~m}^{-2}\right), \mathrm{SW}_{\text {out }}$ $\left(-149 \mathrm{~W} \mathrm{~m}^{-2}\right), Q_{\text {melt }}\left(-26 \mathrm{~W} \mathrm{~m}^{-2}\right)$ and $Q_{\text {lat }}\left(-0.2 \mathrm{~W} \mathrm{~m}^{-2}\right)$. As an energy source, net shortwave radiation $\left(\mathrm{SW}_{\text {net, }}\right.$ $+28 \mathrm{~W} \mathrm{~m}^{-2}$; see Table 2 ) is of almost equal importance to $Q_{\text {sens }}\left(+24 \mathrm{~W} \mathrm{~m}^{-2}\right)$ because of small $\mathrm{SW}_{\mathrm{in}}$. The stronger monsoon influence at glacier2 is also apparent in the very small negative $Q_{\text {lat }}$ associated with only slight mass loss by sublimation compared to glacier1 (Table 2). This is in

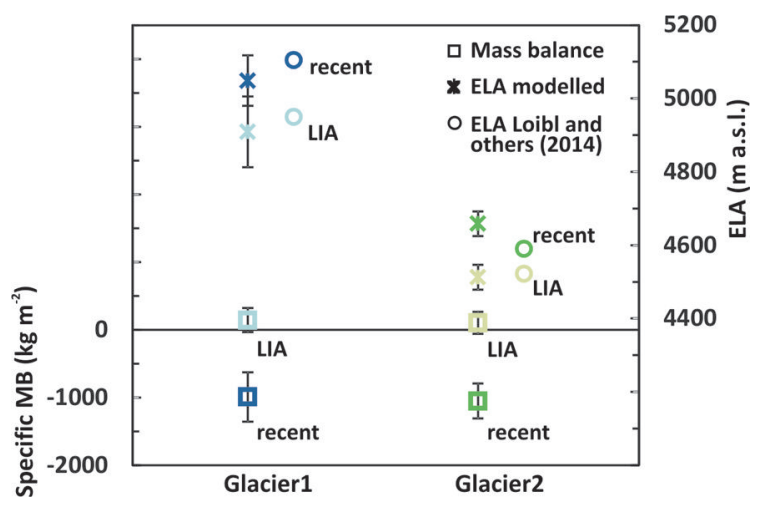

Fig. 4. Average annual $M B$ and ELA for the two glaciers shown in Figure 1 over the period 2000-12 and for LIA climate as calculated from COSIMA results. To reconstruct LIA conditions, PSF and ATO are varied to support a zero glacier MB. Given MB and ELA are the mean of the sets of reasonable PSF/ATO combinations for each glacier with average annual altitudinal gradients and the respective seasonal varying gradients (combinations noted with asterisk in Table 3). Error bars give the range of plausible ELA/MB derived from COSIMA runs with PSF/ATO sets that result in a similar average ELA (see Fig. 2) or in a zero glacier MB. Uncertainties related to the sensitivity analysis are also included. Error ranges for ELA include DEM uncertainty $( \pm 20 \mathrm{~m})$. agreement with the findings of Yang and others (2013) at Parlung No. 94 glacier. At both glaciers, $Q_{\text {lat }}$ becomes positive in summer when the region receives most of the annual precipitation (Fig. 3). Furthermore, highest values of $T_{\text {air }}$ and $\mathrm{rH}$ are apparent in summer. A similar pattern of positive $Q_{\text {lat }}$ during the summer monsoon period was observed at Chhota Shigri glacier in the western Himalaya by Azam and others (2014). At positive $Q_{\text {lat }}$ with concurrent below-zero air temperature, deposition of vapour contributes to mass gain at the glacier surface (Fig. 3b). At both glaciers the lowest values of $S W_{\text {net }}$ are evident between October and February when small precipitation amounts but frequent precipitation events coincide with low temperatures, resulting in a high albedo $(\alpha)$ (Fig. 3a). During these periods $Q_{\text {sens }}$ clearly dominates the energy input and the energy loss through net longwave radiation $\left(\mathrm{LW}_{\text {net }}\right)$ and $Q_{\text {lat }}$ reaches its maximum in the course of the year (Fig. 3a). Average $\mathrm{SW}_{\text {net }}$ and $\mathrm{LW}_{\text {net }}$ are of a similar order of magnitude at both glaciers (Table 2). Thus, the net radiation balance is small and $Q_{\text {sens }}$ is an important energy source. Glacier mass loss in winter is dominated by sublimation (Fig. 3b). However, the amount of sublimation at glacier2 is negligible (Table 2). Surface melt occurs dominantly in May-September when $\mathrm{LW}_{\text {net }}$ and $Q_{\mathrm{PS}}$ cannot compensate the energy input through $S W_{\text {net }}$ and $Q_{\text {sens }}$ (Fig. 4). At both glaciers, only $7 \%$ of the surface and subsurface meltwater refreezes within the snowpack between 2000 and 2012. Modelling results of Yang and others (2013) imply a similar value of $9 \%$. Refreezing occurs mostly in spring and summer (Fig. 3b), when meltwater is produced at the surface and percolates through the snow layers that are still cold from the winter and spring seasons.

Multi-annual datasets of SEB and MB components for glaciers in Tibet are scarce. Therefore, absolute values of energy and mass fluxes as well as their share of the total flux cannot be independently confirmed. However, similar overall patterns of energy and mass fluxes were observed by, for example, Mölg and others (2012) and Huintjes and 
others (2015a) from SEB/MB simulations at Zhadang glacier using in situ measurements.

\subsection{Reconstructed climate during the LIA}

Since glaciers are in equilibrium at the turning point from an advancing to a retreating regime (Maisch, 1981) the assumption of a zero $\mathrm{MB}$ for the reconstructed LIA maximum glacier areas (Fig. $1 \mathrm{~b}$ and $\mathrm{C}$ ) is appropriate for the LIA glacier conditions in southeastern Tibet.

For glacier1, COSIMA runs with five different PSF/ATO combinations within the given boundaries produce a zero MB (Table 3). The respective average ELA is $4970 \pm$ 36 ma.s.l. For glacier2, COSIMA runs with six different PSF/ATO combinations produce a zero MB. The average ELA is $4529 \pm 1$ ma.s.l. (Table 3). Loibl and others (2014) derived an ELA of $4950 \mathrm{~m}$ a.s.I. for glacier1 and $4522 \mathrm{~m}$ a.s.l. for glacier2 (Table 3) by applying the TRAM method based on LIA moraine evidence (Fig. $1 \mathrm{~b}$ and $\mathrm{c}$ ).

Relating recent and LIA PSF/ATO combinations, an air temperature decrease by $3.0-3.5^{\circ} \mathrm{C}$ at glacier 1 and by $2.5^{\circ} \mathrm{C}$ at glacier2 is theoretically valid while precipitation amounts remain unchanged compared to present-day conditions. However, the same amount of precipitation during the LIA as in the contemporary climate is not realistic (Loibl and others, 2014). Considering the reconstructed LIA ELA from Loibl and others (2014), the modelled ELA for glacier1 with the PSF/ ATO sets $0.81 /-1^{\circ} \mathrm{C}$ (ELA $4937 \mathrm{~m}$ a.s.I.) and $1.0 / \pm 0^{\circ} \mathrm{C}$ (ELA 5003 m a.s.I.; Table 3) agree best. COSIMA results also reveal that colder but drier climate leads to a lower ELA than determined by Loibl and others (2014), whereas warmer but wetter conditions lead to a higher ELA although the average $\mathrm{MB}$ is zero in either case. A similar interrelation is also mentioned by $\mathrm{Xu}$ (2014): glaciers with high accumulation rates and moderate air temperature can sustain the same size with a smaller accumulation area than glaciers under low accumulation rates and lower temperatures. The realistic LIA parameter sets for glacier1 suggest that average precipitation during the LIA was increased by approximately $13-25 \%$ while mean air temperature was approximately $1-2^{\circ} \mathrm{C}$ lower compared to recent climate.

At glacier2, LIA model runs with the PSF/ATO combinations $1.45 /-2{ }^{\circ} \mathrm{C}$ and $1.55 /-1.8^{\circ} \mathrm{C}$ result in an ELA of $4529 \mathrm{~m}$ a.s.I. and agree best with the LIA ELA from Loibl and others (2014) which is $4522 \mathrm{ma.s.l}$. (Table 3). These parameter sets suggest a LIA climate in which average precipitation amounts were increased by approximately 10 $20 \%$ and respective mean air temperature was approximately $1.8-2{ }^{\circ} \mathrm{C}$ lower than in the period 2000-12.

The LIA climate obtained from COSIMA can be related to independent palaeoclimatic reconstructions. Tree-ringbased reconstructions of LIA climate are scarce in the eastern Nyainqêntanglha Range. The most sophisticated palaeo-air temperature reconstruction available to date is provided by Zhu and others (2011), indicating $\sim 2^{\circ} \mathrm{C}$ lower average annual air temperatures than today during the LIA glacier maximum. The results of Grießinger and others (2011) and Wernicke and others (2014) indicate higher than present precipitation and $\mathrm{rH}$, respectively, for the whole LIA.

The results provided by COSIMA are consistent with palaeoclimatic proxy records. However, the validity of these results is clearly limited because additional deviations in $\mathrm{rH}$, $N, \mathrm{SW}_{\text {in, }} \mathrm{LW}_{\text {in }}$ and ws compared to recent climate are very likely but are not considered in this study. If variations of these parameters for the LIA were included as well, more parameter combinations resulting in the same $\mathrm{MB}$ and ELA as given in this study might be obtainable. Thus, our conclusion on air-temperature and precipitation changes during the LIA can only provide a general indication of possible changes while absolute values must be treated with caution due to the partly speculative nature of the boundary conditions of the model runs.

Changes in precipitation and mean air temperature during the LIA cause changes in the SEB and MB components of both glaciers through various feedback mechanisms. The colder and wetter conditions during the LIA cause a decrease in $\mathrm{SW}_{\text {net }}$ due to increased snowfall and a higher albedo (Table 2). Both $\mathrm{LW}_{\text {in }}$ and $Q_{\text {sens }}$ decrease because of decreasing $T_{\text {air }}$. Thus, the energy loss through $L W_{\text {net }}$ increases. $Q_{\mathrm{G}}$ tends to become less negative (glacier1) or more positive (glacier2) in association with a more positive $Q_{C}$. The glacier surface cools because of lower $T_{\text {air }}$ and more energy is transferred from the glacier interior to the surface. Calculated changes in $Q_{G}$ between recent and LIA climate are within the range of uncertainty of the subsurface temperature scheme of COSIMA (Huintjes and others, 2015a).

The processes described for the LIA as simulated by COSIMA cause $Q_{\text {melt }}$ to be considerably smaller than for the recent climate (Table 2). Less surface melt and increased solid precipitation are the main factors influencing the zero MB (Table 2). A thicker snowpack and decreased snow temperatures increase the proportion of refreezing at both glaciers. At glacier1, $11 \%$ of the surface and subsurface meltwater refreezes. At glacier2 the proportion increases to $14 \%$.

\subsection{Sensitivity analysis}

Running COSIMA with seasonally varying gradients for glacier1 and glacier2 for the reasonable PSF/ATO combinations derived with average annual gradients for recent and LIA climate yields an overall ELA lowering and a less negative glacier-wide $\mathrm{MB}$ estimate compared to the model runs with average annual gradients (Table 3 ). The resulting glacier-wide $\mathrm{MB}$ at glacier1 and glacier2 for the LIA are $+285 \pm 5 \mathrm{~kg} \mathrm{~m}^{-2} \mathrm{a}^{-1}$ and $+207 \pm 5 \mathrm{~kg} \mathrm{~m}^{-2} \mathrm{a}^{-1}$, respectively. Clearly, the PSF/ATO sets optimized to return a zero MB with annually averaged gradients do not result in a zero $M B$ with seasonally varying gradients. Consequently, new runs with seasonally varying gradients and adjusted PSF/ATO sets to obtain a zero $\mathrm{MB}$ for the LIA are performed as documented below and in Table 3 .

In order to consider these results relating to the $M B$ and ELA for both glaciers, we further compute mean $M B$ and ELA for all those PSF/ATO sets that turned out to be reasonable using annually averaged gradients, both for annually averaged and seasonally varying gradients. The respective combinations are indicated with an asterisk in Table 3. Likewise, the estimation of the range of uncertainties corresponds to the range in MB/ELA values resulting from PSF/ATO sets with both annually averaged and seasonally varying gradients. This procedure results in overall glacier-wide $\mathrm{MB}$ of $-992 \pm 366 \mathrm{~kg} \mathrm{~m}^{-2} \mathrm{a}^{-1}$ and $-1053 \pm$ $258 \mathrm{~kg} \mathrm{~m}^{-2} \mathrm{a}^{-1}$ over 2000-12 for glacier1 and glacier2, respectively (Fig. 4). The corresponding ELA are 5049 49 ma.s.l. (glacier 1 ) and $4659 \pm 13 \mathrm{ma.s.l.}$ (glacier2) (Fig. 4). For LIA conditions, glacier-wide MB are $+142 \pm$ $176 \mathrm{~kg} \mathrm{~m}^{-2} \mathrm{a}^{-1}$ and $+104 \pm 163 \mathrm{~kg} \mathrm{~m}^{-2} \mathrm{a}^{-1}$ for glacier1 and glacier2, respectively (Fig. 4). The corresponding ELA are 
$4909 \pm 77$ m a.s.l. (glacier 1 ) and $4512 \pm 14$ m a.s.l. (glacier2) (Fig. 4).

Differences in $\mathrm{MB}$ and ELA between annual average and seasonally varying gradients are caused by several feedback mechanisms. At glacier1, total precipitation amounts increase during post-monsoon and winter due to the application of steeper elevation gradients (Table 2). Furthermore, the snow/rain transition is shifted to lower elevations because the temperature lapse rate is larger. As a consequence, more snowfall is simulated and a thicker snowpack persists over a longer period which affects both accumulation and ablation. At glacier2, total precipitation amounts increase in winter due to the application of a larger precipitation gradient (Table 2). During pre-monsoon and monsoon, total precipitation amounts decrease but a stronger temperature lapse rate yields an elevation decrease of the snow/rain transition. Thus, more snowfall is simulated in lower glacier regions, especially in the seasons most affected by snow-albedo feedback.

To derive similar ELA and MB using seasonally varying gradients of temperature and precipitation compared to those derived with COSIMA applying average annual gradients, several PSF/ATO combinations for both glaciers were tested (Table 3). For the period 2000-12 the modelled ELA with the PSF/ATO sets $0.69 /+2.5^{\circ} \mathrm{C}$ and $0.61 /+2{ }^{\circ} \mathrm{C}$ (ELA $5102 \mathrm{~m}$ a.s.I.) for glacier 1 and $1.25 / \pm 0^{\circ} \mathrm{C}$ (ELA $4642 \mathrm{~m}$ a.s.l.) for glacier2 agree best with the ELA from Loibl and others (2014; Table 3). Respective PSF/ATO sets for LIA climate are $0.81 /+0.5^{\circ} \mathrm{C}$ and $0.69 /-0.5^{\circ} \mathrm{C}$ for glacier 1 and $1.45 /-1.5^{\circ} \mathrm{C}$ and $1.35 /-2^{\circ} \mathrm{C}$ for glacier2 (Table 3 ).

These parameter sets for COSIMA simulations with seasonally varying precipitation and temperature gradients suggest a LIA climate in which average precipitation amounts were increased by approximately $8-20 \%$ and respective mean air temperature was approximately 1.5 $2.5^{\circ} \mathrm{C}$ lower than in the period 2000-12. The derived relative changes are mostly within the ranges derived with average annual gradients.

\section{CONCLUSION}

This study presents a new application of the surface energyand mass-balance model COSIMA. The model is used to investigate modern glacier SEB and MB characteristics and LIA glacier configurations, based solely on remote-sensing and meteorological input data from an atmospheric model. Air temperature and precipitation from HAR are varied within realistic limits for two glaciers in the eastern Nyainqêntanglha Range so that the average ELA calculated with COSIMA for 2000-12 agrees with the remote-sensing derived ELA of Loibl and others (2014). For the LIA climate, PSF/ATO sets are varied so that the average glacier MB is close to zero. It is shown that different combinations of PSF and ATO can produce either the same overall ELA or the same MB. Realistic PSF/ATO sets for the LIA were constrained by comparing the modelled LIA ELA with the respective ELA derived from remote-sensing based glacier area reconstruction. Relating recent and LIA PSF/ATO combinations for both glaciers suggests a LIA climate in which average precipitation was increased by approximately $10-25 \%$ and mean air temperature was approximately $1-2{ }^{\circ} \mathrm{C}$ lower than in the period $2000-12$. The derived climate agrees with the few independent palaeoclimatic reconstructions available for southeastern Tibet
(Grießinger and others, 2011; Zhu and others, 2011; Wernicke and others, 2014).

Applying seasonally varying air temperature and precipitation gradients instead of annual mean gradients results in less negative $M B$ and ELA lowering at both glaciers when considering the same PSF/ATO sets. The main reasons for this are increased precipitation and an elevation decrease of the snow/rain transition in different seasons due to the application of higher temperature and precipitation gradients.

To derive similar results using seasonally varying gradients of temperature and precipitation compared to those derived using average annual gradients, additional PSF/ATO combinations for both glaciers were applied. Reasonable parameter sets suggest a LIA climate in which average precipitation amounts were increased by approximately $8-20 \%$ and respective mean air temperature was approximately $1.5-2.5^{\circ} \mathrm{C}$ lower than in the period 2000-12. The derived relative changes are mostly within the ranges derived with average annual gradients.

However, the validity of these results is clearly limited because additional deviations in $\mathrm{rH}, \mathrm{N}, \mathrm{SW}_{\mathrm{in}}, \mathrm{LW}_{\text {in }}$ and ws compared to recent conditions are very likely but are not considered in this study. If these parameters were allowed to vary for LIA conditions, more parameter combinations might result in the same $\mathrm{MB}$ and ELA as those presented in this study. Another limitation of this study is the neglect of ice dynamics. Thus, our conclusion on air-temperature and precipitation changes during the LIA can only provide an order of magnitude. Absolute values include a large range of uncertainty.

During 2000-12, average $\mathrm{SW}_{\text {net }}$ and $\mathrm{LW}_{\text {net }}$ are of a similar order of magnitude at both glaciers. Thus, the net radiation balance is small and $Q_{\text {sens }}$ is an important energy source. Mass loss by sublimation is very small, reflecting the strong influence of the moist monsoonal air masses during summer. Changes in precipitation and mean air temperature during the LIA cause changes in the SEB and MB components of both glaciers through various feedback mechanisms. Colder and wetter conditions during the LIA cause a decrease in $\mathrm{SW}_{\text {net }}$ due to increased snowfall and a higher albedo. A thicker snowpack and decreased snow temperatures increase the proportion of refreezing from $7 \%$ to $11 \%$ (glacier1) and $14 \%$ (glacier2). The overall glacier-wide MB estimate for $2000-12$ is $-992 \pm 366 \mathrm{~kg} \mathrm{~m}^{-2} \mathrm{a}^{-1}$ and $-1053 \pm 258 \mathrm{~kg} \mathrm{~m}^{-2} \mathrm{a}^{-1}$ for glacier1 and glacier2, respectively. This result supports the overall finding of aboveaverage mass loss for glaciers in southeastern Tibet.

In summary, COSIMA constrained by morphological observations provides results consistent with the few available palaeoclimatic proxy records. In accordance with the observed topographical and climatological gradients in the study area, the two studied glaciers show distinctly different interannual MB patterns for the period 2000-12. A detailed analysis of this spatial heterogeneity and the relevant forcing mechanisms are promising aims for future studies to further disentangle the complex climate-topography-glacier interactions in the eastern Nyainqêntanglha Range. A next step for further studies would be to carry out additional model runs including variations of relative humidity and cloud cover which would allow the assessment of further effects on the radiation budget. Furthermore, including the dynamic response of glaciers during LIA and recent climate is an important aspect to be considered in future studies. 


\section{AUTHOR CONTRIBUTIONS}

E.H., D.L., F.L. and C.S. designed the study, E.H. and D.L. wrote the paper, E.H. and C.S. developed COSIMA, E.H. conducted the numerical modelling, D.L. performed glacier mapping and calculated the ELA, C.S. and F.L. helped in writing the paper. All authors continuously discussed the results and further developed the analysis.

\section{ACKNOWLEDGEMENTS}

This work was supported by the German Research Foundation (DFG) Priority Programme 1372, 'Tibetan Plateau: Formation-Climate-Ecosystems' within the DynRG-TiP ('Dynamic Response of Glaciers on the Tibetan Plateau to Climate Change') project under the codes SCHN 680/3-1, SCHN 680/3-2, SCHN 680/3-3, LE 730-28 and by the German Federal Ministry of Education and Research (BMBF) Programme 'Central Asia-Monsoon Dynamics and GeoEcosystems' (CAME) within the WET project ('Variability and Trends in Water Balance Components of Benchmark Drainage Basins on the Tibetan Plateau') under the code 03G0804E. We thank the Department of Ecology, Chair of Climatology, Technical University of Berlin, for providing hourly HAR data. We thank two anonymous reviewers, the scientific editor, Francesca Pellicciotti, and the chief editor, Graham Cogley, for valuable suggestions that improved the manuscript.

\section{REFERENCES}

Azam MF and 6 others (2014) Processes governing the mass balance of Chhota Shigri Glacier (western Himalaya, India) assessed by point-scale surface energy balance measurements. Cryosphere, 8(6), 2195-2217 (doi: 10.5194/tc-8-2195-2014)

Benn DI and Lehmkuhl F (2000) Mass balance and equilibrium-line altitudes of glaciers in high-mountain environments. Quat. Int., 65-66, 15-29 (doi: 10.1016/S1040-6182(99)00034-8)

Bräuning A (2006) Tree-ring evidence of Little Ice Age glacier advances in southern Tibet. Holocene, 16(3), 369-380 (doi: 10.1191/0959683606hl922rp)

Bräuning A and Lehmkuhl F (1996) Glazialmorphologische und dendrochronologische Untersuchungen neuzeitlicher Eisrandlagen Ost- und Südtibets. Erdkunde, 50, 341-359

Domrös M and Peng G (1988) The climate of China. Springer, Berlin

Gabbi, J, Carenzo M, Pellicciotti F, Bauder A and Funk M (2014) A comparison of empirical and physically based glacier surface melt models for long-term simulations of glacier response. J. Glaciol., 60(224), 1140-1154 (doi: 10.3189/2014JoG14J011)

Gardelle J, Berthier E, Arnaud Y and Kääb A (2013a) Region-wide glacier mass balances over the Pamir-Karakoram-Himalaya during 1999-2011. Cryosphere, 7(4), 1263-1286 (doi: 10.5194/ tc-7-1263-2013)

Gardelle J, Berthier E, Arnaud Y and Kääb A (2013b) Corrigendum to 'Region-wide glacier mass balances over the Pamir-Karakoram-Himalaya during 1999-2011'. Cryosphere 7(6), 18851886 (doi: 10.5194/tc-7-1885-2013)

Gardner AS and 16 others (2013) A reconciled estimate of glacier contributions to sea level rise: 2003 to 2009. Science 340(6134), 852-857 (doi: 10.1126/science.1234532)

Grießinger J, Bräuning A, Helle G, Thomas A and Schleser G (2011) Late Holocene Asian summer monsoon variability reflected by $\delta^{18} \mathrm{O}$ in tree-rings from Tibetan junipers. Geophys. Res. Lett., 38(3), 1-5 (doi: 10.1029/2010GL045988)

Heynen M, Miles E, Ragettli S, Buri P, Immerzeel W and Pellicciotti $\mathrm{F}$ (2016) Air temperature variability in a high elevation catchment of the central Himalaya. Ann. Glaciol., 57(71),
212-222 (doi: 10.3189/2016AoG71A076) (see paper in this issue)

Huintjes E and 11 others (2015a) Evaluation of a coupled snow and energy balance model for Zhadang glacier, Tibetan Plateau, using glaciological measurements and time-lapse photography. Arct. Antarct. Alp. Res. 47(3), 573-590 (doi: 10.1657/ AAAR0014-073)

Huintjes E, Neckel N, Hochschild V and Schneider C (2015b) Surface energy and mass balance at Purogangri ice cap, central Tibetan Plateau, 2001-2011. J. Glaciol., 61(230), 1048-1060 (doi: 10.3189/2015JoG15J056)

Immerzeel WW, Petersen L, Ragettli S and Pellicciotti F (2014) The importance of observed gradients of air temperature and precipitation for modeling runoff from a glacierized watershed in the Nepalese Himalayas. Water Resour. Res., 50(3), 2212-2226 (doi: 10.1002/2013WR014506)

Juszak I and Pellicciotti F (2013) A comparison of parameterisations of incoming longwave radiation over melting glaciers: model robustness and seasonal variability. J. Geophys. Res. Atmos., 118, 1-20 (doi: 10.1002/jgrd.50277)

Kattel DB, Yao T, Yang K, Tian L, Yang G and Joswiak D (2012) Temperature lapse rate in complex mountain terrain on the southern slope of the central Himalayas. Theor. Appl. Climatol., 113(3-4), 671-682 (doi: 10.1007/s00704-012-0816-6)

Klok EJ and Oerlemans J (2002) Model study of the spatial distribution of the energy and mass balance of Morteratschgletscher, Switzerland. J. Glaciol., 48(163), 505-518 (doi: 10.3189/172756502781831133)

Kumar L, Skidmore AK and Knowles E (1997) Modelling topographic variation in solar radiation in a GIS environment. Int. J. Geogr. Inf. Sci., 11(5), 475-497 (doi: 10.1080/ 136588197242266)

Loibl D and Lehmkuhl F (2014) Glaciers and equilibrium line altitudes of the eastern Nyainqêntanglha Range, SE Tibet. J. Maps, 11(4), 575-588 (doi: 10.1080/17445647.2014.933451)

Loibl D, Lehmkuhl F and Grießinger J (2014) Reconstructing glacier retreat since the Little Ice Age in SE Tibet by glacier mapping and equilibrium line altitude calculation. Geomorphology, 214, 22-39 (doi: 10.1016/j.geomorph.2014.03.018)

Loibl D and 6 others (2015) Toward a late Holocene glacial chronology for the eastern Nyainqêntanglha Range, southeastern Tibet. Quat. Sci. Rev., 107, 243-259 (doi: 10.1016/ j.quascirev.2014.10.034)

MacDougall AH and Flowers GE (2010) Spatial and temporal transferability of a distributed energy-balance glacier melt model. J. Climate, 24(5), 1480-1498 (doi: 10.1175/2010JCLI3821.1)

MacDougall AH, Wheler BA and Flowers GE (2011) A preliminary assessment of glacier melt-model parameter sensitivity and transferability in a dry subarctic environment. Cryosphere, 5(4), 1011-1028 (doi: 10.5194/tc-5-1011-2011)

Maisch M (1981) Glazialmorphologische und gletschergeschichtliche Untersuchungen im Gebiet zwischen Landwasser- und Albulatal (Kt. Graubünden, Schweiz). Zürich

Maussion F, Scherer D, Mölg T, Collier E, Curio J and Finkelnburg R (2014) Precipitation seasonality and variability over the Tibetan Plateau as resolved by the High Asia Reanalysis. J. Climate, 27(5), 1910-1927 (doi: 10.1175/JCLI-D-13-00282.1)

Mölg T, Maussion F, Yang W and Scherer D (2012) The footprint of Asian monsoon dynamics in the mass and energy balance of a Tibetan glacier. Cryosphere, 6(6), 1445-1461 (doi: 10.5194/ tc-6-1445-2012)

Mölg T, Maussion F and Scherer D (2014) Mid-latitude westerlies as a driver of glacier variability in monsoonal High Asia. Nature Climate Change, 4(1), 68-73 (doi: 10.1038/nclimate2055)

Möller M, Schneider C and Kilian R (2007) Glacier change and climate forcing in recent decades at Gran Campo Nevado, southernmost Patagonia. Ann. Glaciol., 46, 136-144 (doi: 10.3189/172756407782871530)

Molnar P, Boos WR and Battisti DS (2010) Orographic controls on climate and paleoclimate of Asia: thermal and mechanical roles 
for the Tibetan Plateau. Annu. Rev. Earth Planet. Sci., 38(1), 77-102 (doi: 10.1146/annurev-earth-040809-152456)

Neckel N, Kropáček J, Bolch T and Hochschild V (2014) Glacier mass changes on the Tibetan Plateau 2003-2009 derived from ICESat laser altimetry measurements. Environ. Res. Lett., 9(1), 014009 (doi: 10.1088/1748-9326/9/1/014009)

Pfeffer WT and 18 others (2014) The Randolph Glacier Inventory: a globally complete inventory of glaciers. J. Glaciol. 60(221), 537-552 (doi: 10.3189/2014JoG13J176)

Rabus B, Eineder M, Roth A, and Bamler R (2003) The shuttle radar topography mission - a new class of digital elevation models acquired by spaceborne radar. ISPRS J. Photogramm. Remote Sens., 57, 241-262 (doi: 10.1016/S0924-2716(02)00124-7)

Su Z and Shi Y (2002) Response of monsoonal temperate glaciers to global warming since the Little Ice Age. Quat. Int., 97-98, 123-131 (doi: 10.1016/S1040-6182(02)00057-5)

Tshering P and Fujita K (2016) First in situ record of decadal glacier mass balance (2003-14) from the Bhutan Himalaya. Ann. Glaciol., 57(71), 289-294

Wernicke J, Grießinger J, Hochreuther P and Bräuning A (2014) Variability of summer humidity during the past 800 years on the eastern Tibetan Plateau inferred from $\delta^{18} \mathrm{O}$ of tree-ring cellulose. Climate Past Discuss. 10(4), 3327-3356 (doi: 10.5194/cpd-103327-2014)

Xu X (2014) Climates during Late Quaternary glacier advances: glacier-climate modeling in the Yingpu Valley, eastern Tibetan Plateau. Quat. Sci. Rev., 101, 18-27 (doi: 10.1016/j.quascirev. 2014.07.007)

Xu X and Yi C (2014) Little Ice Age on the Tibetan Plateau and its bordering mountains: evidence from moraine chronologies. Global Planet. Change, 116, 41-53 (doi: 10.1016/j.gloplacha. 2014.02.003)
Yang B, Bräuning A, Dong Z, Zhang Z and Keqing J (2008) Late Holocene monsoonal temperate glacier fluctuations on the Tibetan Plateau. Global Planet. Change, 60(1-2), 126-140 (doi: 10.1016/j.gloplacha.2006.07.035)

Yang W and 6 others (2011) Summertime surface energy budget and ablation modeling in the ablation zone of a maritime Tibetan glacier. J. Geophys. Res., 116(D14), D14116 (doi: 10.1029/2010JD015183)

Yang W, Yao T, Guo X, Zhu M, Li S and Kattel DB (2013) Mass balance of a maritime glacier on the southeast Tibetan Plateau and its climatic sensitivity. J. Geophys. Res. Atmos., 118(17), 9579-9594 (doi: 10.1002/jgrd.50760)

Yao $\mathrm{T}$ and 14 others (2012) Different glacier status with atmospheric circulations in Tibetan Plateau and surroundings. Nature Climate Change, 2(9), 663-667 (doi: 10.1038/ nclimate1580)

Zheng B, Zhao X, Li T and Wang C (1999) Features and fluctuation of the Melang Glacier in the Mainri Mountain. J. Glaciol. Geocryol., 21, 145-150

Zhou SZ, Chen FH, Pan BT, Cao JX, Li JJ and Derbyshire E (1991) Environmental change during the Holocene in western China on a millennial timescale. Holocene, 1(2), 151-156 (doi: 10.1177/ 095968369100100207)

Zhu H-F, Shao X-M, Yin Z-Y, Xu P, Xu Y and Tian H (2011) August temperature variability in the southeastern Tibetan Plateau since AD 1385 inferred from tree rings. Palaeogeogr., Palaeoclimatol., Palaeoecol., 305(1-4), 84-92 (doi: 10.1016/j.palaeo.2011. 02.017)

Zhu H, Xu P, Shao X and Luo H (2013) Little Ice Age glacier fluctuations reconstructed for the southeastern Tibetan Plateau using tree rings. Quat. Int., 283, 134-138 (doi: 10.1016/j.quaint. 2012.04.011) 